\title{
IDENTIFIKASI PENYAKIT YANG MENYERANG BIBIT SENGON (Paraserianthes moluccana (Miq.), Barneby \& J.W. Grimes) DI PERSEMAIAN DAN PENGENDALIANNYA
}

\author{
Maharani Mustika Putri*, Yayang Nurahmah dan Illa Anggraeni \\ Pusat Penelitian dan Pengembagan Hutan Bogor \\ Jl. Gunung Batu Nomor 5, Bogor Po. Box. 331 \\ Telp. (0251)8631238 Fax. (0251)7520005 \\ *e-mail: mmustikaputri94@yahoo.com
}

\begin{abstract}
Identification of Disease Attacks and Control on Sengon (Paraserianthes moluccana (Miq.), Barneby \& J.W. Grimes) Seedling in Nursery

Plant diseases are one of the problems on seedlings of sengon (Paraserianthes moluccana (Miq.), Barneby \& J.W. Grimes). Diseases infestation on the seedlings can cause a problem at the plantation. Diseases interference has a big value, since sengon is a perenial tree that need a long time until harvesting. The objective of this research was to identify the pathogens of diseases that infested on sengon seedlings. The research was conducted at Nursery of Forestry Research Institute Center with 250 plants of sengon. Disease incidence and severity were measured and the data was analyzed with SAS program. The research result showed that disease infested at the nursery of sengon seedlings was powdery mildew (Oidium sp.). The observation showed that the incidence of powdery mildew was $78.00 \%$, while the severity was 39,12\%. Based on the leaves number, the compound leaves were categorized into four category, i.e. very few, few, plenty, and very plenty. Sengon in the category of very plenty compound leaves (31-49 leaves) showed a significant difference against the disease incidence of powdery mildew, with the lowest incidence of $24,23 \%$.
\end{abstract}

Keywords : Nursery, Oidium sp., powdery mildew, Paraserianthes moluccana

\begin{abstract}
ABSTRAK
Penyakit merupakan salah satu permasalahan yang terjadi dalam pembibitan sengon (Paraserianthes moluccana (Miq.), Barneby \& J.W. Grimes). Terjadinya investasi penyakit di dalam bibit menyebabkan penanaman menjadi terganggu. Gangguan tersebut sangat besar artinya mengingat bahwa sengon merupakan tanaman tahunanyangmembutuhkan waktu yang panjang sampai pemanenan.Penelitian ini bertujuan untuk mengidentifikasi patogen penyebab penyakit pada pembibitan. Penelitian dilakukan di persemaian Kelompok Peneliti Perlindungan Hutan, Pusat Penelitian dan Pengembangan hutan Bogor menggunakan 250 tanaman sengon. Peubah yang diamati adalah insidensi dan intensitas penyakit dan data dianalisis menggunakan analisis ragam program SAS untuk melihat keterkaitan antara jumlah daun majemuk dengan intensitas serangan. Hasil penelitian menunjukkan bahwa penyakit yang menyerang bibit sengon adalah embun tepung (Oidium sp.). Hasil penelitian menunjukkan insdensi penyakit embun tepung mencapai $78 \%$ sedangkan intensitas serangan tertinggi mencapai 39,12\%. Berdasarkan jumlahnya, daun majemuk dikategorikan ke dalam empat kategori, sangat sedikit, sedikit, banyak, dan sangan banyak. Tanaman pada kategori jumlah daun majemuk sangat banyak (31-40 daun) menunjukkan perbedaan nyata terhadap intensitas serangan embun tepung dengan intensitas penyakit paling rendah yaitu $24,23 \%$.
\end{abstract}

Kata kunci : bibit, embun tepung, Oidium sp., sengon.

\section{PENDAHULUAN}

Sengon (Falcataria moluccana (Miq.) Berneby and J.W Grime) merupakan pohon yang serba guna, dari mulai daun hingga perakarannya dapat dimanfaatkan untuk beragam keperluan. Sengon di Indonesia mempunyai nama daerah cukup banyak 
diantaranya albizia, bae, bai, jeungjing, jeungjing laut, jing laut, rare, salawaku, salawaku merah, salawaku putih, salawoku, sekat, sengon laut, sengon sabrang, sika, sika bot, sikas, tawa sela, wai, wahagom, wiekkie. Sedangkan nama di luar Indonesia antara lain Batai (Malaysia Barat, Sabah, Philipina, Inggris, Amerika Serikat, Perancis, Spanyol, Italia, Belanda, Jerman); kayu machis (Sarawak); puah (Brunei) (Martawijaya dkk (1989 ). Tanaman sengon pernah dijuluki sebagai pohon ajaib (miracle tree) karena dapat tumbuh dengan cepat (fast growing species) dan dapat beradaptasi pada berbagai keadaan lingkungan. Bila ditanam di tanah yang subur dan iklim yang sesuai tingginya dapat mencapai 7 meter pada umur satu tahun, pada umur 3tahun dapat mencapai 18 meter dan pada umur 9 atau 10 tahun tingginya mencapai 30 meter, tinggi maksimum sengon sekitar 45 meter dengan diameter $100 \mathrm{~cm}$. Tanaman sengon bersifat multifungsi dan memberikan dampak ganda, baik sebagai tanaman produksi maupun sebagai tanaman konservasi dan reboisasi (Santoso, H.B. 1992; Alrasjid, 1973; Martawijaya et al., 1989). Kemampuan sengon untuk dapat mencegah erosi dimanfaatkan oleh Departemen Lingkungan Hidup dan Kehutanan untuk membuat kebijakan menggalakkan "sengonisasi" di sekitar aliran sungai. Selain itu, tujuan dari menanam sengon yaitu untuk dimanfaatkan kayunya. Saat ini sengon banyak diusahakan di kawasan hutan tanaman, perkebunan maupun di kebun-kebun milik rakyat (hutan rakyat) di Pulau Jawa dan di luar Pulau Jawa. Perdagangan kayu rakyat sampai saat ini cukup stabil. Pemanfaatan kayu yang berasal dari hutan rakyat sebagai bahan baku industri cenderung meningkat seiring dengan semakin berkurangnya bahan baku untuk industri yang berasal dari hutan alam. Walaupun kayu sengon merupakan jenis kayu dengan harga jual yang tidak begitu tinggi, namun ketertarikan masyarakat untuk membudidayakan sengon tetap tinggi (Mulyana et al., 2012).

Pada umumnya tanaman sengon diperbanyak dengan biji. Biji sengon yang dijadikan benih, harus terjamin mutunya. Benih yang baik adalah benih yang berasal dari induk tanaman sengon yang memiliki sifat-sifat yang unggul, bentuknya tegak lurus dan tegar, serta bebas dari hama dan penyakit (Badrunasar et al., 2011).Untuk meningkatkan perkecambahan benih sengon diperlukan perlakuan pendahuluan, diantaranya merendam benih di dalam air $80^{\circ} \mathrm{C}$ selama 15 - 30 menit. Setelah itu, benih direndam di dalam air dingin selama 24 jam. Pembibitan sengon harus dilakukan di lokasi yang memiliki naungan atau paranet (Mulyana et al., 2012).

Dalam pengembangan dan budidaya sengon, hama dan penyakit merupakan salah satu faktor pembatas dalam pertumbuhannya, dimana pada waktu yang lalu hal ini tidak pernah diperhitungkan. Hasil pengamatan selama ini selain karat tumor, ada beberapa hama dan penyakit primer yang menyerang sengon antara lain hama kupu kuning (Eurema sp)., penggerek batang (Xystrocera festiva), ulat kantong (Pteroma sp., Amatissa sp.,Clania sp.,), hama uret (Lepidiota stigma, Animala varicolor, Anomala viridis, Phyllopagha bidentata dan phyllopagha helleri); Sedangkan penyakit yang menyerang sengon antara lain penyakit akar merah (Ganoderma pseudoffereum), penyakit embun tepung (Oidium sp.) dan penyakit rebah kecambah (Fusarium sp., Rhizoctonia sp., Pythium sp.) (Anggraeni et al., 2014).

Kerugian yang ditimbulkan tidak hanya dalam bentuk uang, tetapi karena hilangnya daya berkecambah, baik sewaktu masih disimpan, dalam pengiriman, sesudah disemai,ataupun terjadinya investasi penyakit di dalam bibit sehingga penanaman menjadi terganggu. Gangguan tersebut sangat besar artinya mengingat bahwa sengon merupakan tanaman berumur panjang sehingga butuh waktu yang lamaapabila terjadi kegagalan dalam penanaman dan mengharuskan melakukan penanaman kembali. Oleh karena itu, perlu diketahui jenis-jenis penyakit yang menyerang sengonpada tahap awal dimulai dari proses pembibitan.

\section{BAHAN DAN METODE}

\section{Bahan dan Alat}

Bahan yang digunakan untuk penelitian ini yaitu benih sengon,media pasir, media tanah (steril), sekam kering, biofungisida berbahan aktif fungi Trichoderma sp., fungisida berbahan aktif tebuconazole, akuades steril, alkohol 70\%, spirtus, kertas tisu, kapas, dan $\mathrm{NaClO}$. Alat yang 
digunakangelas obyek, kaca penutup, alat pemotong (gunting dan scalpel), pinset, jarum ose, lampu Bunsen, tabung Erlenmeyer, autoklaf, mikroskop, kamera, ruang isolasi (LAF : Laminary Air Flow), cangkul, polibag, kayu, sendok, gelas takar, dan sarung tangan.

\section{Metode}

1. Penanaman dan Pemeliharan

Penanaman dilakukan mulai dari biji, sebelum disemaikan biji sengon tersebut mendapat perlakuan terlebih dahulu. Biji sengondirendam dengan fungisida berbahan aktif tebuconazole selama 2 jam, kemudian ditiriskan selama 10 menit, dan direndam kembali menggunakan air panas selama 24 jam, ditiriskan selama seharian di dalam sungkup, dan kemudian disemaikan menggunakan media pasir. Setelah 7 hari disapih dan dipindahkan ke media dalam polibag, media terdiri dari campuran tanah, sekam padi (tanah 3 : sekam 1), biofungisida berbahan aktif fungi Trichoderma sp. (2 gram per polibag). Pemeliharaan dilakukan dengan penyiraman setiap pagi.

\section{Pengambilan Data}

Pengambilan data dilakukan dengan mengamati bibit sengon yang berumur 3 bulan di persemaian, baik yang terserang atau tidak terserang penyakit. Jumlah sampel yang diamati sebanyak 250 bibit.

\section{Parameter Pengamatan}

Parameter yang diamati adalah gejala, presentase dan intensitas serangan penyakit pada bibit sengon yang berumur 3 bulan. Penghitungan persentase serangan dilakukan dengan membandingkan jumlah tanaman yang terserang dengan jumlah seluruh tanaman yang ada (dalam \%).

Presentase Serangan $=\frac{\text { Jumlah tanaman terserang penyakit }}{\text { Jumlah seluruh tanaman }} \times 100 \%$

Perhitungan intensitas serangan dilakukan dengan cara membandingkan jumlah daun majemuk terserang dengan total jumlah daun majemuk per bibit (dalam \%).

Intensitas Serangan $=\frac{\text { Jumlah daun majemuk terserang }}{\text { Jumlah total daun majemuk }} \times 100 \%$
Hasil pengukuran intensitas serangan tersebut kemudian diolah menggunakan analisia ragam program SAS untuk melihat keterkaitan antara jumlah daun majemuk dengan intensitas serangan.

4. Identifikasi dan Determinasi Patogen Penyakit

Daun yang terserang diidentifikasi di Laboratorium Penyakit, KeltiPerlindungan Hutan, Puslitbang Hutan. Identifikasi pathogen dilakukan dengan pembuatan preparat basah sederhana.Pembuatan preparat basah dimana bagian jaringan daun tanaman yang sakit diiris setipis mungkin (transparan), irisan diletakkan pada gelas obyek (dibagian tengah) yang sudah diberi setetes air. Kemudian gelas obyek ditutup sedemikian rupa sehingga tidak terjadi gelembung udara. Preparat diamati di bawah mikroskop. Apa yang dilihat dari preparat langsung maupun dicocokkan dengan deskripsi ciri-ciri patogen. Identifikasi dilakukan dengan pengamatan secara mikroskopis (bentuk hifa, ada tidaknya septa, bentuk spora dll) dan makroskopis (gejala penyakit dan tanda penyakit di lapangan). Berdasarkan ciri-ciri tersebut fungi patogen diidentifikasi dengan menggunakan kunci determinasi serta dideskripsikan dengan acuan pustaka antara lain Alexopoulos dan Mims (1979); Barnett \& Hunter (2006); Dwidjoseputro (1978); Streets (1980) dan Agrios (2005).

\section{HASIL DAN PEMBAHASAN}

\section{Gejala Penyakit Embun Tepung (Powdery Mildew)}

Gejala penyakit embun tepung sangat mudah dikenali karena pada permukaan tanaman yang terserang terdapat lapisan putih seperti tepung (Gambar 1). Gejala awal ditandai dengan bercak-bercak putih tak beraturan bercak menyatu sampai akhirnya melapisi seluruh permukaan bagian tanaman yang terserang. Bagian bibitsengonyang diserang adalah bagian daun mulai dari pucuk (Gambar 2) hingga daun dibawahnya, tangkai daun, ranting dan batang. Berdasarkan pengamatan secara mikroskopis lapisan putih seperti tepung adalah sekumpulan miselium, konidium dan konidiofor dari fungi patogen. 


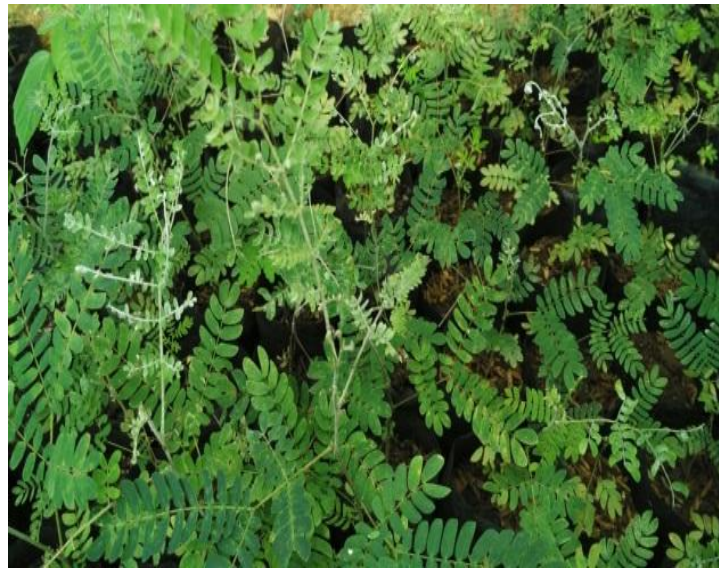

(a)

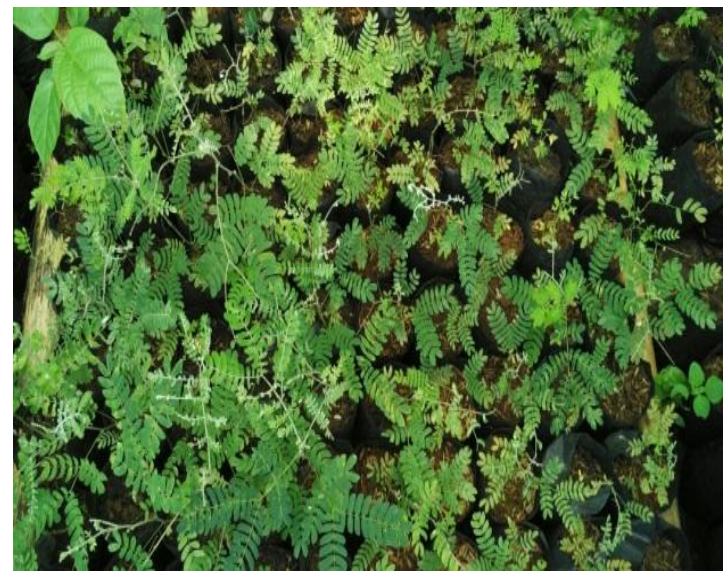

(b)

Gambar 1. (a) dan (b) Serangan Penyakit Embun Tepung Pada Bibit Sengon di Persemaian (Foto : Yayang Nurahmah).

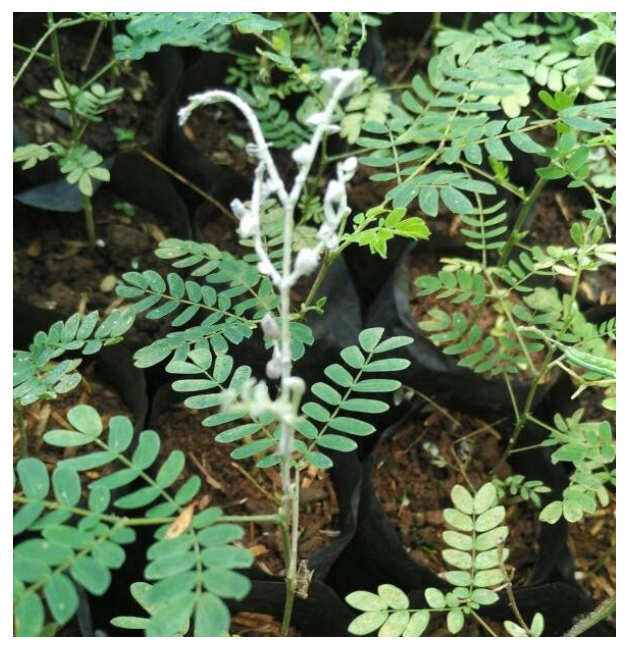

Gambar 2. Gejala Serangan Penyakit Embun Tepung pada Bibit Sengon Berupa Lapisan Putih (Foto : Yayang Nurahmah).

Daun muda yang terinfeksi pada stadia awal pertumbuhannya sangat terganggu dan bentuknya menjadi tidak normal (malformasi) yaitu daun mengkerut, keriting/bergelombang dan mengeras (Gambar 2), akhirnya daun kering dan rontok. Pengaruh infeksi jauh lebih parah pada daun muda dibandingkan dengan daun tua, bagian pucuk daun mengalami kematian (die-back). Daun tua yang terinfeksi tidak memperlihatkan perubahan kecuali makin menebalnya lapisan putih pada permukaan daun.

\section{Identifikasi Penyakit}

Hasil pengamatan secara mikroskopis dan pengamatan secara makroskopis, diketahui bahwa penyebab penyakit embun tepung pada bibit sengon adalah fungi Oidium sp. (Kelas Deuteromycetes/stadium aseksual) atau Erysiphe sp. (Ascomycetes/stadium seksual), secara lengkap klasifikasinya adalah sebagai berikut (Dwidjoseputro, 1978) :

Divisio : Mycota

Subdivisio : Eumycotina

Class : Ascomycetes

Subclass : Hemiascomycetidae 


$\begin{array}{ll}\text { Ordo } & \text { : Erysiphales } \\ \text { Famili } & \text { : Erysiphaceae } \\ \text { Genus } & \text { : Oidium (Erysiphe) } \\ \text { Species } & \text { : Oidium sp. Sacc. }\end{array}$

Oidium sp. dikenal sebagai parasit obligat yang hanya dapat hidup pada jaringan yang hidup. Pengamatan secara mikroskopis menunjukkan bahwa konidium fungi Oidium sp. berbentuk elips (bulat telur) tidak berwarna/hialin (Gambar 3). Infeksi Oidium adalah melalui stomata (lubang alami) kemudian konidia berkecambah membentuk haustorium yang masuk ke dalam sel epidermis dan menyerap hara yang terdapat di dalam sel epidermis tersebut (Boyce, 1961). Penyebaran penyakit dapat melalui angin, air, serangga dan manusia.

\section{Presentase dan Intensitas Serangan Penyakit}

Berdasarkan hasil pengamatan, bibit sengon yang terserang penyakit embun tepung mencapai $78 \%$ dari 250 bibit. Intensitas serangan terendah sebesar $6 \%$ dan tertinggi mencapai $100 \%$. Hasil pengamatan tersebut dikelompokkan berdasarkan jumlah daun majemuk yang dimiliki oleh bibit sengon. Intensitas serangan embun tertinggi yaitu 39,12\% ditunjukkan oleh bibit yang memiliki jumlah daun sedikit (11-20 daun). Hasil

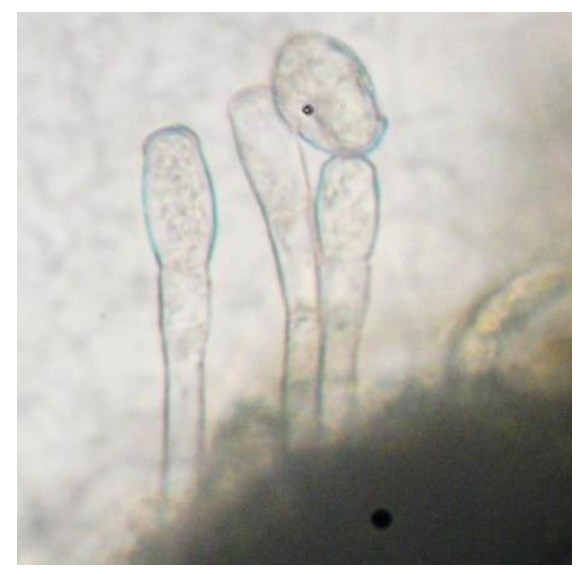

(a) tersebut lebih tinggi jika dibandingkan dengan intensitas serangan pada bibit dengan jumlah daun majemuk sangat sedikit (1-10). Hal tersebut mungkin disebabkan karena bibit dengan jumlah daun sangat sedikit sudah terlebih dulu mengalami serangan embun tepung sehingga saat dilakukan pengamatan daun pada bibit tersebut sudah mengalami kerontokkan akibat embun tepung. Bibit sengon dengan jumlah daun majemuk sangat banyak (31 - 40 daun) memiliki intensitas serangan terendah yaitu 24,23\% (Tabel 1). Bibit sengon dengan jumlah daun lebih banyak cenderung menaungi bibit sengon dengan jumlah daun yang lebih sedikit, sehingga pada bibit tersebut terjadi kelembaban yang lebih tinggi dari pada bibit dengan jumlah daun majemuk lebih banyak. Kelembaban tinggi tersebut menyebabkan intensitas serangan menjadi lebih tinggi.

Bibit sengon yang memiliki daun majemuk relatif banyak menandakan bahwa bibit tersebut relatif sehat jika dibandingkan dengan yang memiliki daun majemuk sedikit. Kondisi inang tersebut yang menyebabkan perbedaan intensitas serangan embun tepung. Kemampuan patogen dalam menginfeksi akan berkurang saat inang dalam keadaan sehat. Kondisi inang yang tidak sehat akan menyebabkan peningkatan kerentanan terhadap patogen (Widyastuti et al., 2005).

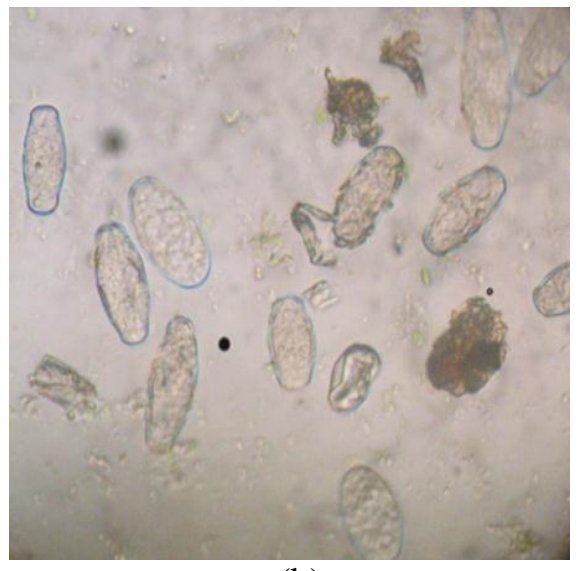

(b)

Gambar 3. Penampang Mikroskopis: (a) Konidiofor, (b) Kodinia dari Oidium sp. (Perbesaran 400x) (Foto : Illa Anggraeni) 
Tabel 1. Intensitas Serangan Embun Tepung pada Bibit Sengon Berdasarkan Jumlah Daun Majemuk

\begin{tabular}{cc}
\hline Kategori Jumlah Daun Majemuk & Intensitas Serangan (\%) \\
\hline SS & $35.06 \pm 17,87 \mathrm{a}$ \\
S & $39.12 \pm 11,14 \mathrm{a}$ \\
B & $36.60 \pm 3,67 \mathrm{a}$ \\
SB & $24.23 \pm 4,79 \mathrm{~b}$ \\
\hline
\end{tabular}

SS (sangat sedikit) : Jumlah daun majemuk $1-10, \mathrm{~S}$ (sedikit) : jumlah daun majemuk $11-20$, B (banyak) : jumlah daun majemuk $21-30$ (banyak), SB (sangat banyak) = jumlah daun majemuk $31-40$.

Selain dipengaruhi faktor internal yaitu tanaman itu sendiri, perkembangan penyakit tersebut juga sangat tergantung dari faktor eksternal. Faktor eksternal yang mungkin mempengaruhi tingkat serangan penyakit embun tepung di lahan antara lain suhu, kelembaban, curah hujan dan media tanam yang digunakan. Suhu optimum untuk perkecambahan konidiumnya adalah $25^{\circ}$ C. Cendawan tersebut mampu berkembang pada cuaca kering, dan konidiumnya dapat berkecambah dalam udara dengan kelembaban nisbi rendah (5075\%) (Budiarto et al., 2006). Lokasi pembibitan sengon tersebut memiliki curah hujan yang relatif tinggi. Kondisi lingkungan dengan kelembaban dan curah hujan tinggi sangat mendukung perkembangan cendawan tersebut (Sinclair, 1989). Suhu tinggi beberapa jam yang kemudian terjadi hujan, akan memicu perkecambahan konidia jamur yang berada diatas permukaan daun. Spora yang sudah berada di permukaan tanaman akan segera berkecambah dan membentuk haustorium. Penetrasi akan terjadi dalam beberapa jam setelah perkecambahan konidia (Triwiratno, 2014).

\section{Upaya Pencegahan dan Pengendalian Penyakit}

Pengendalian penyakit embun tepung dapat dilakukan melalui pengendalian kultur teknis, alami dan kimia. Pengendalian secara kultur teknis dapat dilakukan dengan cara membuat kondisi pertanaman tidak cocok untuk perkembangan patogen ini salah satunya dengan pemangkasan atau pengaturan jarak saat persemaian. Hal tersebut dapat mengurangi kelembaban. Pengendalian alam juga dilakukan dengan memanfaatkan biofungisida seperti Ampelomycesquisqualis (Suastika, 2010 dalam Triwiratno, 2014). Serangan yang parah pada tunas muda disarankan untuk dipangkas, kemudian dimasukkan kantong plastik untuk mengurangi penyebaran konidia di kebun (Triwiratno, 2014). Penggunaan daun mimba mampu merusak membran sel jamur Oidium sp., sehingga metabolisme sel terganggu dan pertumbuhan sel terhambat. Perbedaan konsentrasi filtrat daun mimba mempengaruhi pertumbuhan embun tepung, dan filtrat daun mimba paling efektif adalah konsentrasi 60g/l, 80g/l dan 100g/l dengan presentase serangan embun tepung $11 \%$, $14,59 \%$ dan 12,67\% (Munah, 2006). Pengendalian kimia paling efektif dilakukan menjelang bertunas dan diulang saat daun muda menggunakan fungisida berbahan aktif benomil (sesuai dengan dosis yang tertera pada tabel) (Anggraeni dan Djatnika, 2000). Untuk penyembuhan penyakit embun tepung dapat dilakukan dengan pemberian cuka kayu (wood venegar) dengan dosis $4 \mathrm{cc} /$ liter air dengan cara disemprot keseluruh bibit sengon.

\section{KESIMPULAN}

Jenis penyakit yang menyerang bibit sengon adalah embun tepung yang disebabkan oleh fungi patogen Oidium sp. dengan tingkat serangan tinggi mencapai 78\% sedangkan intensitas serangan masih tergolong sedang dengan tingkat serangan tertinggi $39,12 \%$. Tanaman pada kategori 
jumlah daun majemuk sangat banyak (3140 daun) menunjukkan perbedaan nyata terhadap intensitas serangan embun tepung dengan intensitas penyakit paling rendah yaitu $24,23 \%$.

\section{DAFTAR PUSTAKA}

Agrios, G.N. 2005. Plant Pathology. $5^{\text {th }}$ eds. Elsevier Academic Press. USA.

Alexopoulos, C.J. and C.W. Mims. 1979. Introductory Mycology. John Wiley $\&$ Sons. New York.

Alrasjid, A. 1973. Beberapa Keterangan Tentang Albizia falentaria (L) Foxberg. Lembaga Penelitian Hutan. Bogor.

Anggraeni, I dan I. Djatnika. 2000. Upaya Pengendalian Embun Tepung pada Bibit Acacia mangiuim dengan Benomil, Tepung Gambir dan Kulit Buah Mahoni. Prosiding KongresNasional XV dan Seminar Ilmiah Perhimpunan Fitopatologi Indonesia 16 - 18 September 1999. Jurusan Hama dan Penyakit, Fakultas Pertanian. Universitas Jenderl Soedirman. Purwokerto.

Anggraeni, I., U.W. Darmawan, A. Ismanto. 2014. Insiden Penyakit pada Kecambah Sengon (Falcataria molucana (Miq.) Berneby and J.W Grimes) dan Uji Patogenisitasnya. Jurnal Ilmu-ilmu Biologi dan Kimia. 4 (2). 181-186.

Badrunasar, Anas, dan Y. Nurahmah. 2011. Pertelaan Jenis Pohon Koleksi Arboretum Balai Penelitian Teknologi Agroforestry. Balai Penelitian Teknologi Agroforestry. Ciamis.
Barnett, H. L and B. B. Hunter. 2006. Illustrated Genera of Imperfect Fungi. Burges Publishing Company. Minneapolis - USA.

Boyce, J.S. 1961. Forest Pathology. Third dition. McGraw Hill Book Company, Inc. New York.

Budiarto K, S. Yogo, M. Ruud, W. Sri. 2006. Budidaya Krisan Bunga Potong. Pusat Penelitian dan Pengembangan Hortikultura. Jakarta.

Dwidjoseputro. 1978. Pengantar Mikologi. Penerbit Alumni. Bandung.

Martawijaya, A. I., Y. I. Kartasujana, S. A. Mandang, Prawira, K. Kadir. 1989. Atlas Kayu Indonesia Jilid II. Pusat Penelitian dan Pengembangan Hasil Hutan. Bogor.

Mulyana, D., C. Asmarahman, I. Fahmi. 2012. Petunjuk Praktis Pembibitan Jabon dan Sengon. Agromedia. Jakarta.

Munah, M. 2006. Uji Efektifitas Dosis Filtrat Daun Mimba (Azadirachtanindica) dalam Menghambat Perkembangan Embun Tepung (Oidiumtingitanium) pada Tanaman Jeruk Siam (Citrusreticulata). Pustaka karya ilmiah Indonesia, Kementerian Riset dan Teknologi Republik Indonesia. Jakarta.

Santoso, H. B. 1992. Budidaya Sengon. Kanisius. Yogyakarta.

Sinclair, J. B. 1989. Threats to Soybean Production in the Tropics. Red leaf blotch and leaf rust. Department of Plant Pathology. Univesity of Illinois at Urbana. 
Streets, R. B. 1980. Diagnosis Penyakit

Tanaman (Terjemahan : Imam

Santoso). The University of Arizona

Press. Tuscon - Arizona. USA

Triwiratno, A. 2014. Penyakit Embun

Tepung (Oidiumtingitanium carter).

Balai Penelitian Tanaman Jeruk dan

Buah Subtropika. Badan Penelitian dan Pengembangan Pertanian. https://balitjestro.litbang.pertanian.go .id/penyakit-embun-tepung-oidiumtingitanium-carter/. Diakses tanggal 14 Februari 2017.

Widyastuti, S. M., Sumardi, Harjono. 2005.

Patologi Hutan. Gadjah Mada

University Press. Yogyakarta 